\title{
Selenium ameliorates Staphylococcus aureus-induced inflammation in bovine mammary epithelial cells by inhibiting activation of TLR2, NF-KB and MAPK signaling pathways
}

Heng Wang ${ }^{1,2+}$ (D), Chongliang Bi $i^{1,2,3+}$, Yinjie Wang ${ }^{1,2}$, Jun Sun ${ }^{1,2}$, Xia Meng ${ }^{1,2}$ and Jianji $\mathrm{Li}^{1,2^{*}}$

\begin{abstract}
Background: Staphylococcus aureus (S. aureus) internalization into bovine mammary epithelial cells (bMECs) is considered an important pathogenic mechanism for the establishment of mastitis. Given the interesting link between selenium (Se) status and mastitis, our objective was to prove that Se was essential to suppress proinflammatory mediators, in part, by modulation of Toll-like receptor2 (TLR2), nuclear factor kappaB (NF-kB) and mitogen activated protein kinase (MAPK) signal transduction pathway in bMECs.

Results: Results showed that Se $(0 \sim 16 \mu \mathrm{M})$ did not affect the growth of bMECs. The mRNA expression of TLR2, Myeloid differentiation factor 88 (Myd88), Interleukin-1 receptor-associated kinase4 (Irak4), Interleukin-1 receptorassociated kinase1 (Irak1) and TNF receptor-associated factor6 (Traf6) in TLR2 signal pathway were increased or significantly increased by S. aureus. Se played an important role in regulating the genes expression of TLR2, Myd88, Traf6 but not in controlling the expression of Irak4 and Irak1. In addition, Se exerted strong inhibitory effects on the genes expression of tumor necrosis factor-alpha (TNF-a), interleukin-1 $\beta$ (IL-1 $\beta$ ) and interleukin-6 (IL-6) induced by S. aureus. To further investigate the possible signaling mechanisms involved in the processes, we analyzed the role of MAPK and NF-KB signaling pathway in inflammation response in S. aureus-stimulated bMECs in vitro. Results showed that the phosphorylation of inhibitory kappaB alpha $(I K B a), p 65, p 38$ and extracellular regulated protein kinase (Erk) were significantly increased in S. aureus-stimulated bMECs. It indicated that $S$. aureus activated NF-KB and MAPK signaling pathway. We also examined the effects of Se on the phosphorylation of $1 k B a, p 65$, p38 and Erk in NF-KB and MAPK signaling pathway, which have well been proved to control the synthesis and release of proinflammatory mediators during inflammation. The findings are exciting, that pretreatment with Se $(4,8 \mu \mathrm{M})$ significantly suppressed the phosphorylation of IkBa, p65, p38 and Erk.
\end{abstract}

Conclusions: These results suggest that Se down-regulates inflammatory mediators TNF- $a, I L-1 \beta$ and IL-6 gene expressions via TLR2, NF-KB and MAPK signaling pathway in S. aureus-stimulated bMECs, which may be responsible for the anti-inflammatory effect of Se.

Keywords: Se, TLR2, NF-KB, MAPK, Mammary

\footnotetext{
* Correspondence: yzjjli@163.com

${ }^{\dagger}$ Heng Wang and Chongliang Bi contributed equally to this work.

${ }^{1}$ College of Veterinary Medicine, Yangzhou University, Yangzhou 225009,

Jiangsu, China

${ }^{2}$ Jiangsu Co-innovation Center for Prevention and Control of Important

Animal Infectious Diseases and Zoonoses, Yangzhou 225009, Jiangsu, China

Full list of author information is available at the end of the article
}

(c) The Author(s). 2018 Open Access This article is distributed under the terms of the Creative Commons Attribution 4.0 International License (http://creativecommons.org/licenses/by/4.0/), which permits unrestricted use, distribution, and

reproduction in any medium, provided you give appropriate credit to the original author(s) and the source, provide a link to the Creative Commons license, and indicate if changes were made. The Creative Commons Public Domain Dedication waiver (http://creativecommons.org/publicdomain/zero/1.0/) applies to the data made available in this article, unless otherwise stated. 


\section{Background}

Bovine mastitis is a frequent and costly disease in the dairy industry [1]. S. aureus internalization into bMECs is considered an important pathogenic mechanism for the establishment of mastitis. In contrast to clinical mastitis, S. aureus-induced mastitis may manifest very diverse degrees of severity, from fulminating gangrenous mastitis with nervous systemic signs to mild local infection with only local signs $[2,3]$. Therefore, it is of prime importance to determine how to detect and eradicate bacteria earlier and control the inflammation [4]. Antibiotics as an effective treatment of bovine mastitis existed many limits such as drug resistance and food safety concerns [5]. Thus, innate immune defense in local against pathogenic microorganisms has already attracted extensive attention.

The epithelium is an important line of defense against pathogenic microorganisms. Beyond the function of milk production, bMECs also equipped with a battery of receptors sensing the presence molecular components of pathogens, which has been verified that these cells are capable of initiating an in vitro innate immune response to pathogenic bacteria $[6,7]$. Among these pattern recognition receptors (PPRs), 13 different TLRs have been well described in mammalian [8]. Some of these receptors span across the cell membrane and bind bacterial ligands with their extracellular domain. TLR2, for example, has been confirmed to be indispensable for $S$. aureus recognition [9]. Successful TLR2 signaling mostly involves the activation of the factor Myd88. Myd88 possesses two remarkable domains, the $\mathrm{N}$-terminal death domain and C-terminal Toll/IL-1R domain (TIR) domain [10]. Ligand binding to the TLR family results in the recruitment of Myd88 to TIR domains of receptors. And the death domain of Myd88 is known to interact with Irak, a serine/threonine kinase harbors a death domain in N-terminal portion by homophilic interaction. Subsequently, another adaptor protein Traf6 is phosphorylated and recruited to Irak [11]. Further, the TLR2-S. aureus interaction leads to the rapid and coordinated activation of various intracellular signaling pathways such as NF- $\mathrm{kB}$ and MAPK [12]. NF- $\mathrm{kB}$ and MAPK signaling pathways, responsible for regulating the expression of cytokines, chemokines, are essential immune mediators during inflammation [13].

Se is an essential micronutrient, which has been investigated for various medical applications such as anti-bacterial, anti-oxidant, anti-inflammatory, and anti-cancer growth [14, 15]. Previous studies have shown the correlation between Se and LPS-induced mammary epithelial cells inflammatory response. Results demonstrated that Se exert beneficial effects to mammary epithelial cells, after the treatment of cells with the LPS. Result also showed that Se could inhibit LPS-induced inflammation response of mammary epithelial cells through the inhibition of NF- $\mathrm{kB}$ and MAPK activation [16]. However, the effect of Se in $S$. aureus-induced bovine mastitis is still unclear. The aim of this study was to investigate the protective effect of Se against $S$. aureus-induced inflammation injury in bMECs and to clarify the associated signaling pathways of Se supplement in $S$. aureus-infected bMECs.

\section{Methods}

bMECs isolation, cell culture, and treatment

bMECs were isolated from udders of lactating cows as previously described and cryopreserved in liquid nitrogen $[17,18]$. Cows were from the University of Yangzhou herd and the protocol was approved by the Animal Care and Ethics Committee of the Yangzhou University (Approval ID: SYXK [Su] 2012-0029). Cells were cultured in Dulbecco's modified Eagle's medium/Ham's F-12 nutrient mixture (DMEM/F12), supplemented with $10 \%$ fetal bovine serum (Gibco, Grand island), $5 \mu \mathrm{g} / \mathrm{mL}$ of insulin, $1 \mu \mathrm{g} / \mathrm{mL}$ of hydrocortisone, and $10 \mathrm{ng} / \mathrm{mL}$ of epidermal growth factor (Sigma, US).

Sodium selenite was diluted in DMEM/F12 medium. S. aureus $\left(29,213\right.$, ATCC) was grown overnight at $37{ }^{\circ} \mathrm{C}$ in $10 \mathrm{~mL}$ Luria-Bertani. The number of $S$. aureus was determined by dilution method of plate counting. Bacteria was then diluted to achieve a multiplicity of infection (MOI) of 1:1 (bacteria:cell) in DMEM/F12. All cells were washed with serum-free medium and serum starved for $1 \mathrm{~h}$ before incubation with Se or $S$. aureus.

\section{Cell viability assay}

To measure cell viability, $1 \times 10^{5}$ cells of bMECs were seeded in 96-well multiplies and cultured in $100 \mu \mathrm{L}$ DMEM/F12 medium at $37{ }^{\circ} \mathrm{C}$ and $5 \% \mathrm{CO}_{2}$. When cells grew to $90 \%$ confluence, all cells were washed twice with phosphate buffer saline (PBS) and serum starved for $1 \mathrm{~h}$ before incubation with $\mathrm{Se}$ in different concentrations for $12 \mathrm{~h}$, and then $10 \mu \mathrm{L}$ of 3-(4,5-dimethylthiazol-2-yl)-2,5-diphenyltetrazolium bromide (Amresco, US) was added to each well and incubated for another $4 \mathrm{~h}$. The formazan product was dissolved using dimethyl sulfoxide (Amresco, US). The optical density was measured at $570 \mathrm{~nm}$ using a microplate reader (Tecan, Austria) [19].

\section{RNA extraction and genes expression analysis}

Total RNA was extracted from infected cells using Trizol reagent (Amresco, US) according to the manufacturer's instructions. Integrity of RNA and reverse transcription were performed as previously described [20]. Reverse transcription-generated cDNA encoding $\beta$-actin, TLR2, Myd88, Irak4, Irak1, Traf6, IL-1 $\beta$, TNF- $\alpha$ and IL-6 were amplified by RT-PCR using selective primers listed in Table 1. Quantitative PCR analysis was carried out as previously described [21]. The PCR reaction system 
Table 1 Primers used in experiment

\begin{tabular}{|c|c|}
\hline Gene & Sequence \\
\hline$\beta$-actin & $\begin{array}{l}\text { F:ACATCCGCAAGGACCTCTA } \\
\text { R:CCATGCCAATCTCATCTCGTT }\end{array}$ \\
\hline TNF-a & $\begin{array}{l}\text { F:CTGCTGACGGGCTTTACC } \\
\text { R:GACTGCAATGCGGCTGAT }\end{array}$ \\
\hline IL-1 $\beta$ & $\begin{array}{l}\text { F:GCTATGAGCCACTTCGTGAGGAC } \\
\text { R:GATTGAGGGCGTCGTTCAGGAT }\end{array}$ \\
\hline IL-6 & $\begin{array}{l}\text { F:TGATGACTTCTGCTITCCCTACCC } \\
\text { R:ATCTTTGCGTTCTITACCCACTCG }\end{array}$ \\
\hline TLR2 & $\begin{array}{l}\text { F:GATGACTACCGCTGTGAC } \\
\text { R:GGTITTGTGGCTCTITTC }\end{array}$ \\
\hline Myd88 & $\begin{array}{l}\text { F:AGCAGCATAACTCGGATAA } \\
\text { R:CAGACACGCACAACTTCA }\end{array}$ \\
\hline Irak4 & $\begin{array}{l}\text { F:TGGCAAAGACAGGACATCTG } \\
\text { R:CACAACTCCCAAACCCTCCTT }\end{array}$ \\
\hline Irak1 & $\begin{array}{l}\text { F:GAGTTCCAACGTCCTTCTGG } \\
\text { R:CTCCCGGTCTTCACGTACTG }\end{array}$ \\
\hline Traf6 & $\begin{array}{l}\text { F:CGGTGACTCTCTCCAGGTGT } \\
\text { R:TGGACATTTGTGACCTGCAT }\end{array}$ \\
\hline
\end{tabular}

contained $10 \mu \mathrm{L}$ of SYBR Green PCR mix (Takara, Japan), $0.8 \mu \mathrm{L}$ of each primer, $2 \mu \mathrm{L}$ of cDNA template, and $6.4 \mu \mathrm{L}$ of diethylpyrocarbonate water.

\section{Western blot analysis}

Total protein was extracted from bMECs using a total protein extraction kit (BioChain, US) and the protein concentrations were determined by bicinchoninic acid protein assay kit (BioChain, US). All cells were respectively pretreated with $\mathrm{Na}_{2} \mathrm{SeO}_{3}(2,4$, and $8 \mu \mathrm{M})$ or left untreated for $12 \mathrm{~h}$ and infected with $S$. aureus $(\mathrm{MOI}=$ 1:1) for $0.5 \mathrm{~h}$. Cell lysates were prepared as described previously [2]. Proteins were loaded into $10 \%$ SDS polyacrylamide gel for electrophoresis, and transferred using sodium phosphate buffer to polyvinylidene fluoride membrane metastasis (Merck Millipore, Germany). The membrane was then hybridized with specific antibodies.

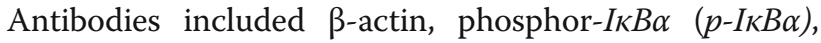
phospho-p65 ( $p-p 65)$, phosphor-p38 ( $p-p 38)$, and phosphor-Erk ( $p$-Erk) (Cell Signaling Technology, US).

\section{Statistical analysis}

All data were presented as mean \pm standard error of mean (sem). The groups were compared by using one-way ANOVA and Dunnett's test. A $p$-value $<0.05$ was considered statistically significant. Unless indicated otherwise, all data were obtained from at least 3 independent experiments.

\section{Results}

\section{The cytotoxicity of se on bMECs}

Results showed that there was no significant effect of $1 \sim 16 \mu \mathrm{mol} / \mathrm{L}$ selenium on cell activity. As selenium concentrations increased further, cell activity was significantly suppressed, compared with the control group $(p<0.001)$. Activity of bMECs fell by $33 \%$ with $32 \mu \mathrm{mol} / \mathrm{L}$ selenium, and by $84 \%$ with $64 \mu \mathrm{mol} / \mathrm{L}$ selenium, which shew cytotoxicity (Fig. 1).

\section{Se inhibits the activation of TLR2 pathway}

As shown in Fig. 2a, the expression of TLR2 were up-regulated after $S$. aureus infection. This effect was significantly blocked by Se at 8 and $10 \mathrm{~h}$ in all group $(p<0.01)$. However at $6 \mathrm{~h}$ no statistically significant differences were shown between Se-pretreatment and control groups.

The genes expression of Myd88 induced by S.aureus were significantly up-regulated $(p<0.001)$ at $8 \mathrm{~h}$ and this effect was blocked by Se in all group $(p<0.001)$ (Fig. 2b). but at $6 \mathrm{~h}$ and $10 \mathrm{~h}$ there was no difference in statistics between all groups.

The gene expression of Irak4 induced by $S$. aureus were increased or significantly increased $(p<0.01$ or $p<0.001)$ at all time point, but Se showed no blocking effect to the mRNA expression of Irak4 (Fig. 2c). Similar to Irak4, the mRNA expression of Irak1 were all up-regulated at any time points $(p<0.05$ or $p<0.001)$ after $S$. aureus infection, and Se showed no blocking effect to the mRNA expression of Irak1 (Fig. 2d).

Compared to the control group, the Traf6 levels increased or significantly increased after $S$. aureus infection $(p<0.05$ or $p<0.001)$ and this effect was blocked by Se in all group $(p<0.001)$ (Fig. 2e) at $6 \mathrm{~h}$. So, the blocking effect of Se on TLR2 signal pathway in the inflammation response of bMECs induced by $S$. aureus was confirmed initially.

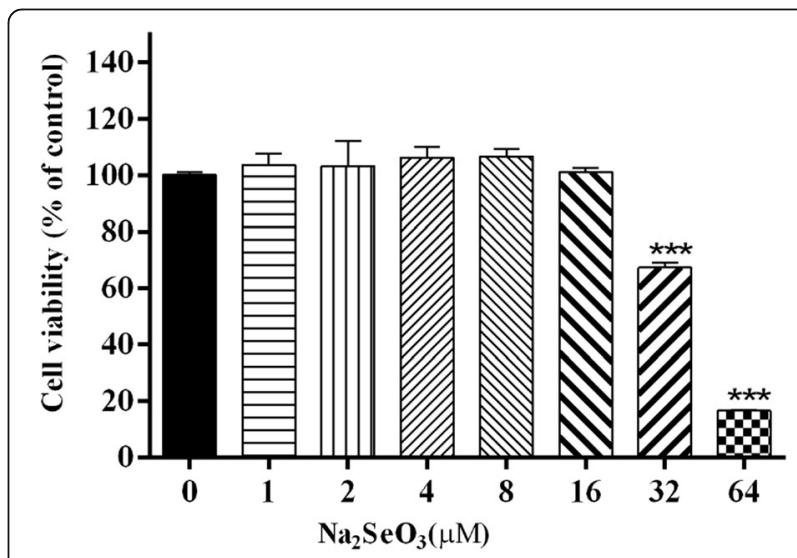

Fig. 1 The cytotoxicity of Se on bMECs. Cell viability was measured by MTT following treatment with various concentrations $(0,1,2,4,8$, $16,32$ and $64 \mu \mathrm{M})$ of Se for $12 \mathrm{~h}$. Cell proliferation was not inbitited by Se in concentration lower than $16 \mu \mathrm{M}$. The data are mean \pm sem $(n=6) .{ }^{* * *} p<0.001$ vs. $0 \mu \mathrm{M}$ 

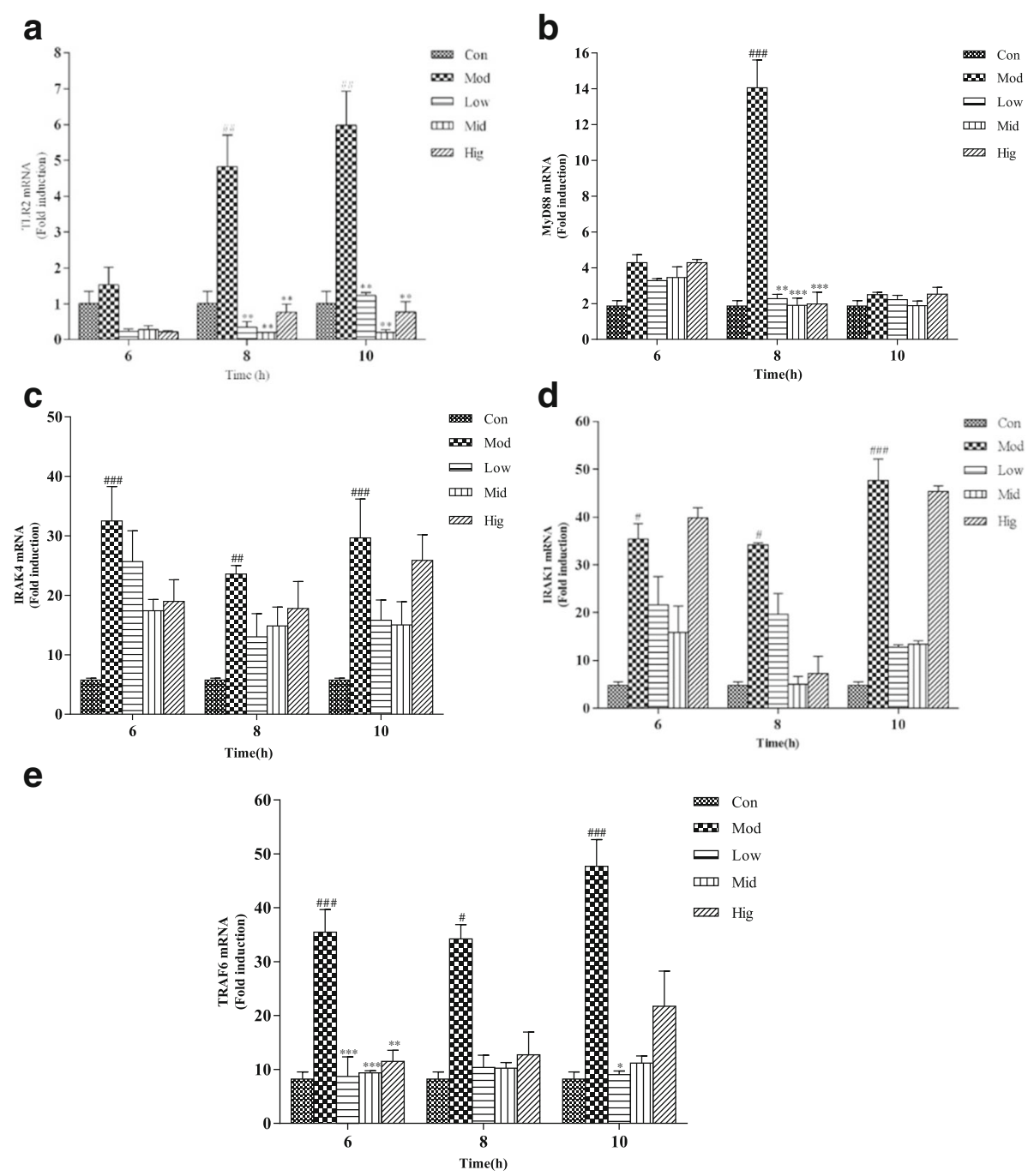

Fig. 2 The effect of Se on TLR2 signaling pathway associate genes induced by S. aureus in bMECs. Cells were incubated with different concentrations of Se or serum-free medium for $12 \mathrm{~h}$ and subsequently treated with $\mathrm{S}$. aureus $(\mathrm{MOI}=1: 1)$ for 0, 6, 8 and $10 \mathrm{~h}$. Total RNA was prepared at the indicated time points after S. aureus treated. The TLR2 (a), Myd88 (b) , Irak4 (c) , Irak1 (d) and Traf6 (e) mRNA expression levels were assayed using qRT-PCR. con = control cells without any treatment; mod = cells treated with $S$. aureus $(\mathrm{MOI}=1: 1)$ only; low $=\operatorname{Se}(2 \mu \mathrm{M})+S$. aureus $(\mathrm{MOI}=1: 1)$; $\mathrm{mid}=\mathrm{Se}(4 \mu \mathrm{M})+\mathrm{S}$. aureus $(\mathrm{MOI}=1: 1)$; high $=\mathrm{Se}(8 \mu \mathrm{M})+\mathrm{S}$. aureus $(\mathrm{MOI}=1: 1)$. The data are shown as mean \pm sem $(n=3) . \# \#$ : $p<0.001$ vs. Con; $: p<0.05$ vs. Mod; ${ }^{* *}: p<0.01$ vs. Mod; ${ }^{* * *}: p<0.001$ vs. Mod

\section{Se weakens the inflammation injury of bMECs induced by}

\section{S. aureus}

The protective effect of Se against $S$. aureus-induced inflammation injury in bMECs was analyzed by qRT-PCR. S. aureus could significantly up-regulate the gene expression of TNF- $\alpha$, IL- $1 \beta$, and IL- 6 at the various time points. But the effect was markedly inhibited by Se (Fig. 3a, b and c). Thus, the anti-inflammatory effect of Se was confirmed in the inflammation response of bMECs induced by $S$. aureus.

\section{Se inhibits the activation of NF-KB pathway}

Protein expression of $p-I \kappa B \alpha$ and $p$ - $p 65$ were up-regulated significantly $(p<0.001)$ by innoculation with $S$. aureus for
$0.5 \mathrm{~h}$ (Fig. 4), which indicated that NF-kB signaling pathway was activated. However, the phosphorylation of $I \kappa B \alpha$ and $p 65$ were suppressed by the addition of $4 \mu \mathrm{M}$ and $8 \mu \mathrm{M}$ Se. So, the higher Se concentration could suppress the inflammatory response by NF- $\mathrm{kB}$ pathway to some extent.

\section{Se inhibits the activation of MAPK pathway}

The phosphorylation of $p 38$ and Erk increased significantly with $S$. aureus or associated with $2 \mu \mathrm{M}$ Se innoculation for $0.5 \mathrm{~h}$, while phosphorylation of $p 38$ and Erk were markedly suppressed by Se at 4 and $8 \mu \mathrm{M}$ (Fig. 5), which suggesting that higher concentration of Se could inhibit 

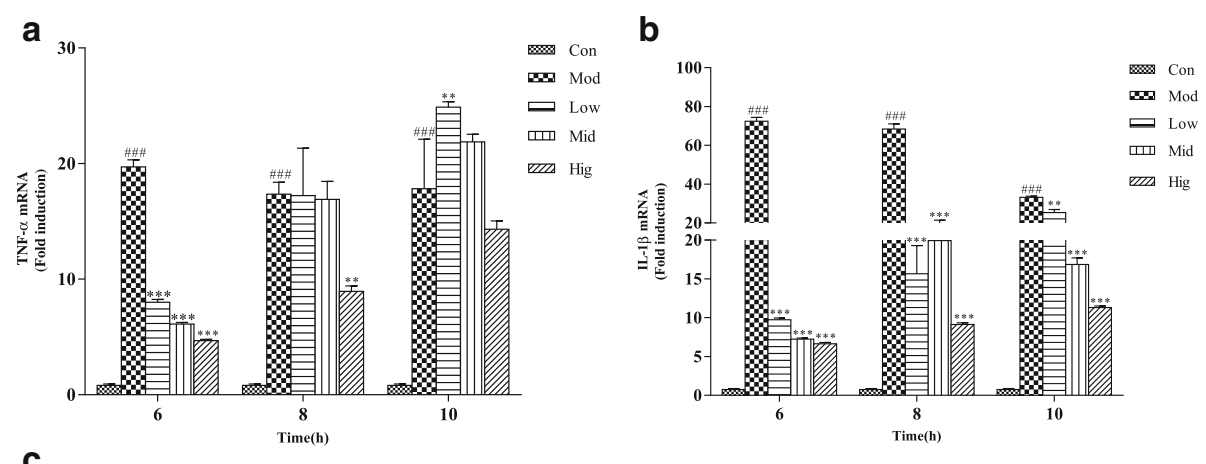

C

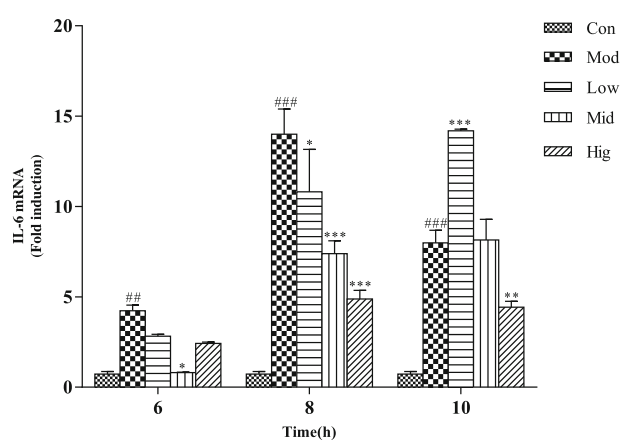

Fig. 3 The effect of Se on gene expression of pro-inflammatory cytokines induced by S. aureus in bMECs. Cells were incubated with various concentrations of Se or serum-free medium for $12 \mathrm{~h}$ and subsequently challenged with $\mathrm{S}$. aureus $(\mathrm{MOI}=1: 1)$ for $0,6,8$, and $10 \mathrm{~h}$. Total RNA was prepared the indicated time points after $S$. aureus injection. The TNF- $\alpha$, IL-1 $\beta$ and IL-6 mRNA expression were quantified using qRT-PCR. con $=$ control cells without any treatment; $\bmod =$ cells treated with $S$. aureus $(\mathrm{MOI}=1: 1)$ only; low $=\operatorname{Se}(2 \mu \mathrm{M})+S$. aureus $(\mathrm{MOI}=1: 1) ; \mathrm{mid}=\mathrm{Se}$ $(4 \mu \mathrm{M})+$ S. aureus $(\mathrm{MOI}=1: 1)$; high $=\operatorname{Se}(8 \mu \mathrm{M})+S$. aureus $(\mathrm{MOI}=1: 1)$. The data are shown as mean $\pm \operatorname{sem}(n=3) .{ }^{\# \#}: p<0.01$ vs. Con; ${ }^{\# \# \#: ~} p<0.001$ vs. Con; ${ }^{*}: p<0.05$ vs. Mod; ${ }^{* *}: p<0.01$ vs. Mod; ${ }^{* * *}: p<0.001$ vs. Mod
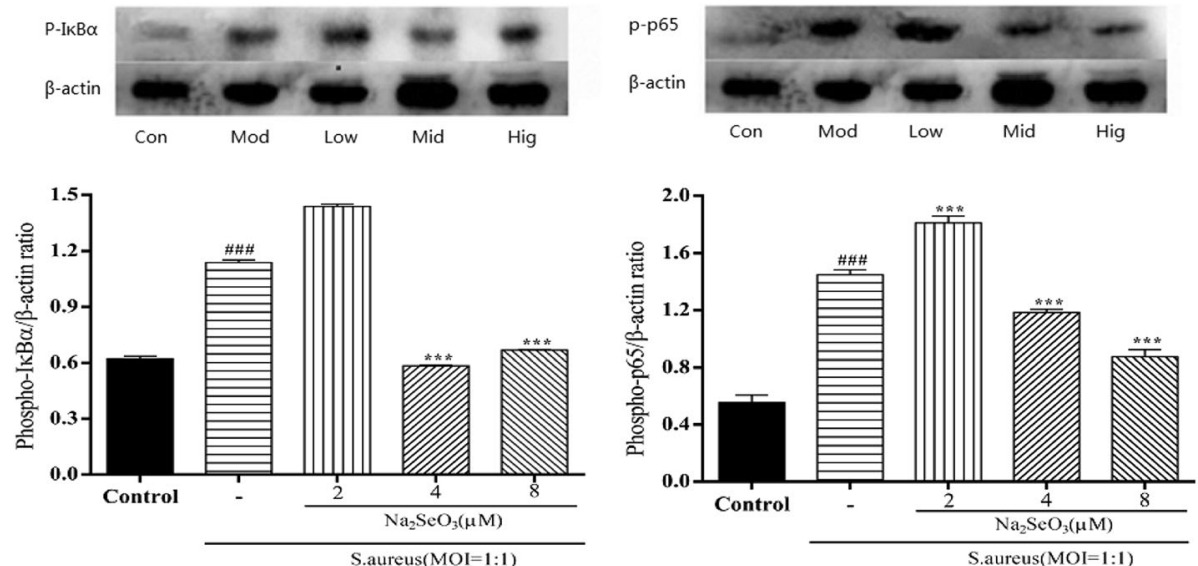

Fig. 4 Effect of Se on S. aureus-induced IKBa and p65 phosphorylation in bMECs. Cells were pretreated with various concentrations $(0,2,4$ and $8 \mu \mathrm{M})$ of Se or serum-free medium for $12 \mathrm{~h}$ before stimulated with S. aureus (MOI $=1: 1)$ for $0.5 \mathrm{~h}$ and then washing twice with PBS. Total proteins were prepared at the indicated time points and subjected to Western blotting. Con $=$ control cells without any treatment; mod $=$ cells treated with S. aureus $(\mathrm{MOI}=1: 1)$ only; low $=\operatorname{Se}(2 \mu \mathrm{M})+S$. aureus $(\mathrm{MOI}=1: 1)$; $\operatorname{mid}=\operatorname{Se}(4 \mu \mathrm{M})+S$. aureus $(\mathrm{MOI}=1: 1)$; high $=\operatorname{Se}(8 \mu \mathrm{M})+S$. aureus $(\mathrm{MOI}=1: 1)$. The data are shown as mean $\pm \operatorname{sem}(\mathrm{n}=3) .{ }^{\# \# t}: p<0.001$ vs. Con; ${ }^{*}: p<0.05$ vs. Mod; ${ }^{* *}: p<0.01$ vs. Mod; ${ }^{* * *}: p<0.001$ vs. Mod. One out of 3 independent experiments is shown 

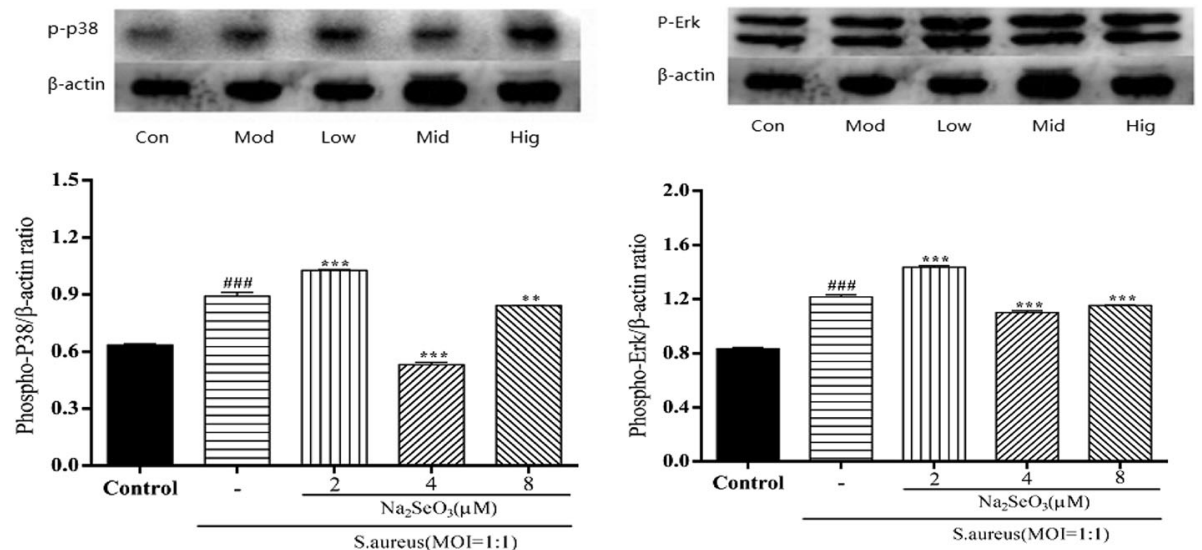

Fig. 5 Effect of Se on S. aureus-induced p38 and Erk phosphorylation in bMECs. Cells were pretreated with various concentrations (0, 2, 4 and $8 \mu \mathrm{M})$ of Se or serum-free medium for $12 \mathrm{~h}$ before stimulated with $\mathrm{S}$. aureus $(\mathrm{MOI}=1: 1)$ for $0.5 \mathrm{~h}$ and then washing twice with PBS. Total proteins were prepared at the indicated time points and subjected to Western blotting. Con = control cells without any treatment; mod $=$ cells treated with $S$. aureus $(\mathrm{MOI}=1: 1)$ only; low $=\mathrm{Se}(2 \mu \mathrm{M})+\mathrm{S}$. aureus $(\mathrm{MOI}=1: 1)$; mid $=\mathrm{Se}(4 \mu \mathrm{M})+\mathrm{S}$. aureus $(\mathrm{MOI}=1: 1)$; high $=\mathrm{Se}(8 \mu \mathrm{M})+\mathrm{S}$. aureus $(\mathrm{MOI}=1: 1)$. The data are shown as mean $\pm \operatorname{sem}(\mathrm{n}=3) .{ }^{\# \# \#}: p<0.001$ vs. Con; ${ }^{*}: p<0.05$ vs. Mod; ${ }^{* *}: p<0.01$ vs. Mod; ${ }^{* * *}: p<0.001$ vs. Mod. One out of 3 independent experiments is shown

the activation of MAPK signaling pathway by suppression of phosphorylation of p38 and Erk.

\section{Discussion}

Se is an essential micronutrient that play an important role in regulating the immune function [22]. Many studies have indicated that Se is involved in several biological activities, including the regulation of inflammation and immunological reaction [23]. The acute and sub-actue toxicity of Se were studies in bMECs, and these results showed that when the concentrations of Se is lower than $16 \mu \mathrm{M}$, the cell viability was not affected, which is also within the normal range of selenium in the dairy cow.

Our previous study supports the hypothesis that TLR2 plays an important role at the early inflammation induced by $S$. aureus [24]. In the meanwhile, Irak was activated via an adaptor protein Myd88 in TLR2 signalling pathway $[25,26]$. In this study, proteins expression of TLR2 signaling pathway were examined by qRT-PCR. Accompanied by the activation of Irak, another adaptor protein Traf 6 is phosphorylated and recruited to Irak in model group. Then, NF- $\mathrm{kB}$ and MAPK signaling pathway were triggered, which were characterized by the releasing of a large number proinflammatory cytokines [27]. Appropriate inflammation response is beneficial for immune cells to fight against infection, but excessive inflammation response will injure the tissues and cells. So the releasing of proinflammatory cytokines must be tightly regulated during the inflammatory response [28]. Our study found that a strong activity of TLR 2 signaling pathway could be triggered by $S$. aureus at about $10 \mathrm{~h}$. Moreover, the gene expression of TNF- $\alpha$, IL- $1 \beta$, and
IL-6 were significantly increased in bMECs induced by $S$. aureus at any time point, which indicated a strong inflammatory response. Se obviously suppressed the mRNA expression of TLR2, Myd88, and Traf6 induced by $S$. aureus at $6,8,10 \mathrm{~h}$. The results support the hypothesis that Se could protect bMECs from $S$. aureus injury by inhibiting the expression of TNF- $\alpha$, IL- 6 and IL-1 $\beta$. Furthermore the effect of Se on TLR2 signaling pathway is mainly regulated by the gene expression of TLR2, Myd88 and Traf6.

NF- $\mathrm{B}$ and MAPK signaling pathways are two classical pathways associated with inflammation, which are important in numerous processes such as immune processes, cell survival and inflammation $[29,30]$. As an accelerant of NF-кB and MAPK, $S$. aureus could strongly enhance the phosphorylation of $I \kappa B \alpha, p 65, p 38$, and Erk, leading to a conformational change of NF- $\kappa B$ and MAPK that evokes NF- $\kappa \mathrm{B}$ and MAPK signaling activity. The different members of NF- $\mathrm{B}$ and MAPK have different downstream targets, and thus play distinct roles in cellular responses. Our results showed that the phosphorylation of $I_{\kappa} B \alpha, p 65, p 38$, and Erk were markedly increased after stimulation with $S$. aureus for $0.5 \mathrm{~h}$., which demonstrated a significant activation of NF-kB and MAPK and subsequently lead to a high expression of pro-inflammation cytokines. Se suppressed the phosphorylation of $I \kappa B \alpha, p 65, p 38, E r k$, which indicating an inhibitory effect of NF-kB and MAPK activity. Therefore, the releasing of pro-inflammatory cytokines were inhibited. Ultimately, the protective effect of Se was validated through blocking TLR2, NF- $\mathrm{BB}$ and MAPK signaling pathways against bMECs inflammatory injury induced by $S$. aureus. 


\section{Conclusions}

This study proved the protective effect of Se on S. aureus-induced inflammation in bMECs. This effect was at least partly achieved by the blocking of TLR2 signaling pathway. On the other hand, Se could decrease the gene expression of pro-inflammation cytokines through mediating the phosphorylation of $I \kappa B \alpha$ and p 65 in NF- $\mathrm{kB}$ pathway and inhibiting the phosphorylation of p38 and Erk in the MAPK pathway. Se reveal potential benefit for the adjuvant therapy of mastitis induced by S. aureus. But other anti-inflammatory associated pathways and targets of Se need to be studied in the future.

\section{Abbreviations}

bMECS: Bovine mammary epithelial cells; MAPK: Mitogen-activated protein kinase; NF-kB: Nuclear factor kappa-light-chain-enhancer of activated B cells.; Se: Selenium.; TLR2: Toll-like receptor 2 .

\section{Funding}

Natural Science Foundation of Jiangsu Province (No. BK20160062, BK2012265), The investigation was supported by the National Natural Science Foundation of China (No. 31302151,31672614), Priority Academic Program Development of Jiangsu Higher Education Institutions (PAPD) and Outstanding Young Backbone Teacher Foundation of Yangzhou University.

\section{Availability of data and materials}

The datasets used and analysed during the current study are available from the corresponding author on reasonable request.

\section{Authors' contributions}

$H W, C B$, and $J$ conceived, designed and performed the majority of the experiments and drafted the manuscript. YW and JS helped with experiments, provided valuable discussion and modified the final manuscript. XM participated in experimental procedures and data analysis. HW, JL, and XM conceived the study, participated in its coordination and helped to revise the manuscript. All authors read and approved the final manuscript.

\section{Ethics approval}

The protocol was approved by the Animal Care and Ethics Committee of Yangzhou University.

\section{Competing interests}

The authors declare that they have no competing interests.

\section{Publisher's Note}

Springer Nature remains neutral with regard to jurisdictional claims in published maps and institutional affiliations.

\section{Author details \\ ${ }^{1}$ College of Veterinary Medicine, Yangzhou University, Yangzhou 225009, Jiangsu, China. ${ }^{2}$ Jiangsu Co-innovation Center for Prevention and Control of Important Animal Infectious Diseases and Zoonoses, Yangzhou 225009, Jiangsu, China. ${ }^{3}$ College of Agriculture Forestry Science, Linyi University, Linyi 276000, Shandong, China.}

Received: 12 February 2018 Accepted: 30 May 2018

Published online: 20 June 2018

\section{References}

1. Günther J, Liu S, Esch K, Schuberth HJ, Seyfert HM. Stimulated expression of TNF- $a$ and IL-8, but not of lingual antimicrobial peptide reflects the concentration of pathogens contacting bovine mammary epithelial cells. Vet Immunol Immunopathol. 2010;135:152-7.

2. Günther J, Kathrin E, Seyfert HM. Comparative kinetics of Escherichia coli and Staphylococcus aureus-specific activation of key immune pathways in mammary epithelial cells demonstrates that S.aureus elicits a delayed response dominated by Interleukin-6 (IL-6) but not by IL-1a or tumor necrosis factor alpha. Infect Immun. 2011;79:695-707.

3. Sutra LB, Poutrel B. Virulence factors involved in the pathogenesis of bovine intramammary infections due to Staphylococcus aureus. J Med Microbiol. 1994:40:79-89.

4. Quesnell RR, Klaessig S, Watts JL, Schukken YH. Bovine intramammary Escherichia coli challenge infections in late gestation demonstrate a dominant antiinflammatory immunological response. J Dairy Sci. 2012;95: 117-26.

5. Dego OK, Oliver SP, Almeida RA. Host-pathogen gene expression profiles during infection of primary bovine mammary epithelial cells with Escherichia coli strains associated with acute or persistent bovine mastitis. Vet Microbiol. 2011;155:291-7.

6. Schukken YH, Günther J, Fitzpatrick J, Fontaine MC, Goetze L, Holst O, et al. Host response patterns of intramammary infections in dairy cows. Vet Immunol Immunopathol. 2011;144:270-89.

7. Rinaldi M, Li RW, Capuco AV. Mastitis associated transcriptomic disruptions in cattle. Vet Immunol Immunopathol. 2010;138:267-79.

8. Akira S, Takeda K. Toll-like receptor. Curr Protoc Immunol. 2015;109:1-14.

9. Yang W, Zerbe H, Petzl W, Brunner RM, Günther J, Draing C. Bovine TLR2 and TLR4 properly transduce signals from Staphylococcus aureus and E. coli, but $S$. aureus fails to both activate NF-kB in mammary epithelial cells and to quickly induce TNF- $a$ and interleukin-8 (CXCL8) expression in the udder. Mol Immunol. 2007:45:1385-97.

10. Takeuchi O, Akira S. Toll-like receptors; their physiological role and signal transduction system. Int Immunopharmacol. 2001;1:625-35.

11. Meads MB, Li ZW, Dalton WS. A novel TNF receptor-associated factor 6 (Traf6) binding domain mediates NF-kB signaling by the common cytokine receptor $\beta$ subunit. J Immunol. 2010;185:1606-15.

12. Hines DJ, Choi HB, Hines RM, Phillips AG, MacVicar BA. Prevention of LPSinduced microglia activation, cytokine production and sickness behavior with TLR4 receptor interfering peptides. PLoS One. 2013;8:e60388.

13. Calzado MA, Bacher S, Schmitz ML. NF-kappaB inhibitors for the treatment of inflammatory diseases and cancer. Curr Med Chem. 2007;14:367-76.

14. Rayman MP. Selenium in cancer prevention: a review of the evidence and mechanism of action. Proc Nutr Soc. 2005;64:527-42.

15. Clark LC, Combs GFJ, Turnbull BW, Slate EH, Chalker DK, Chow J, et al. Effects of selenium supplementation for cancer prevention in patients with carcinoma of the skin. A randomized controlled trial. Nutritional prevention of Cancer study group. J Am Med Assoc. 1996;276:1957-63.

16. Zhang W, Zhang R, Wang T, Jiang H, Guo M, Zhou E, et al. Selenium inhibits LPS-induced pro-inflammatory gene expression by modulating MAPK and NF-kappa B signaling pathways in mouse mammary epithelial cells in primary culture. Inflammation. 2014;37:478-85.

17. Lahouassa H, Moussay E, Rainard P, Riollet C. Differential cytokine and chemokine responses of bovine mammary epithelial cells to Staphylococcus aureus and Escherichia coli. Cytokine. 2007;38:12-21.

18. Porcherie A, Cunha P, Trotereau A, Roussel P, Gilbert FB, Rainard P, Germon $P$. Repertoire of Escherichia coli agonists sensed by innate immunity receptors of the bovine udder and mammary epithelial cells. Vet Res. 2012; 43:14-22.

19. Shimohashi N, Nakamuta M, Uchimura K, Sugimoto R, Lwamoto $H$, Enjoji M, Nawata H. Selenoorganic compound, ebselen, inhibits nitric oxide and tumor necrosis factor-alpha production by the modulation of Jun-nterminal kinase and NF-kappa B signaling pathway in rat kupffer cells. J Cell Biochem. 2000;78:595-606

20. Yu J, Yin P, Liu F, Cheng G, Guo K, Lu A, et al. Effect of heat stress on the porcine small intestine: a morphological and gene expression study. Comp Biochem Physiol. 2010;156:119-28.

21. Yu J, Yin P, Liu F, Cheng G, Guo K, Lu A, et al. Involvement of ERK1/2 signalling and growth-related molecule expression in response to heat stress-induced damage in rat jejunum and IEC-6 cells. Int J Hyperth. 2010;26:538-55.

22. Hoffmann PR, Berry MJ. The influence of selenium on immune responses. Mol Nutr Food Res. 2008:52:1273-80.

23. Kim SH, Johnson VJ, Shin TY, Sharma RP. Selenium attenuates lipopolysaccharide-induced oxidative stress responses through modulation of p38 MAPK and NF-kappa B signaling pathways. Exp Biol Med. 2004;229: 203-13.

24. Wang H, Yu G, Yu H, Gu M, Zhang J, Meng X, et al. Characterization of TLR2, NOD2, and related cytokines in mammary glands infected by Staphylococcus aureus in a rat model. Acta Vet Scand. 2015;57:25-31. 
25. Medzhitov R, Hurlburt PP, Kopp E, Stadlen A, Chen C, Ghose H. Myd88 is an adaptor protein in the toll/L-1 receptor family signaling pathways. Mol Cell. 1998;2:253-8.

26. Muzio M, Ni J, Feng P, Dixit VM. IRAK (Pelle) family member IRAK-2 and Myd88 as proximal mediators of IL-1 signaling. Science. 1997;278:1612-5.

27. Strandberg Y, Gray C, Vuocolo T, Donaldson L, Broadway M, Tellam R. Lipopolysaccharide and lipoteichoic acid induce different innate immune responses in bovine mammary epithelial cells. Cytokine. 2005;31:72-86.

28. Scheibel M, Klein B, Merkle H, Schulz M, Fritsch R, Greten FR, Arkan MC, Schneider G, Schmid RM. IKB $\beta$ is an essential co-activator for LPS-induced IL-1 $\beta$ transcription in vivo. J Exp Med. 2010;207:2621-30.

29. Lee Y, Shin DH, Kim JH, Hong S, Choi D, Kim YJ, Kwak MK, Jung Y. Caffeic acid phenethyl ester-mediated Nrf2 activation and IKB kinase inhibition are involved in NF-kB inhibitory effect: structural analysis for NFKB inhibition. Eur J pharmacol. 2010;643:21-8.

30. Gehart H, Kumpf S, Ittner A, Ricci R. MAPK signalling in cellular metabolism: stress or wellness? EMBO Rep. 2010;11:834-40.

Ready to submit your research? Choose BMC and benefit from:

- fast, convenient online submission

- thorough peer review by experienced researchers in your field

- rapid publication on acceptance

- support for research data, including large and complex data types

- gold Open Access which fosters wider collaboration and increased citations

- maximum visibility for your research: over $100 \mathrm{M}$ website views per year

At BMC, research is always in progress.

Learn more biomedcentral.com/submissions 